BOŻENA ŻEJMO

Uniwersytet Mikołaja Kopernika w Toruniu

(D ORCID: http://orcid.org/oooo-0oo2-2850-6308

\title{
ŚMIECIOWA CODZIENNOŚĆ KONSUMENTA. POWIEŚĆ GENERATION „П” WIKTORA PIELEWINA W ŚWIETLE TEORII PŁYNNEJ NOWOCZESNOŚCI ZYGMUNTA BAUMANA
}

Już od czasów Heraklita świat ludzki jest postrzegany na podobieństwo nieustannie zmieniającego się strumienia wód. Owa koncepcja płynności wszystkiego, co istnieje, zyskała szczególną aktualność na przełomie XX/XXI wieku w obszarze nauk o kulturze i społeczeństwie $^{1}$. W filozofii społecznej Zygmunta Baumana stanowi ona nadrzędną kategorię definiującą cywilizację i kondycję ludzką epoki nowoczesności. Należy jednak od razu zaznaczyć, że polski badacz ma na myśli niezupełnie tę samą koncepcję dynamicznej rzeczywistości²; zostaje ona dopełniona nowymi sensami, determinowanymi konkretnym momentem historycznym. W epoce płynnej nowoczesności

${ }^{1}$ Por.: „Współczesny świat ludzki pojęty jako ‘semioprzestrzeń’ znaków, dyskursów i sensów posiada heraklitejski charakter ulegając nieustannym permutacjom, gdzie każde nasze działanie może zmienić (i zmienia) dotychczasowe znaczenia obiektu bądź znaku”. W. Kalaga, Mgławice dyskursu. Podmiot, tekst, interpretacja, Universitas, Kraków 2001, s. 154.

2 Efezjanin opierał ideę powszechnej zmienności i względności na fizycznokosmicznym porządku i strukturze. Poprzez metaforyczny obraz rzeki sformułował teorię harmonii przeciwieństw, które nie wykluczają się, ale istnieją względem siebie. Nie był zatem zwolennikiem relatywizmu absolutnego, ani skrajnym pesymistą, jak postrzegali go starożytni, przeciwnie - „jego największą zasługę” stanowi „opracowanie [...] fundamentalnego związku między teorią [...] harmonii przeciwieństw [...] a moralnym działaniem" zarówno jednostki, jak i społeczności, a także polityczną praktyką. Zob. M. Fattal, Stowa i czyny u Heraklita, „Archiwum Filozofii Historii i Myśli Społecznej” 2013, vol. 58, s. 11-16. 
Heraklitejski permanentny ruch nie tylko ulega zawrotnemu przyspieszeniu - tempo zmian relatywizuje wartości, uwalnia od norm, zasad i reguł. Głoszone przez starożytnego Efezjanina postulaty zachowania proporcji, nie naruszania harmonii przeciwieństw, dbania o równowagę wszelkich składowych życia indywidualnego oraz społeczno-politycznego, korygowania dominacji jednego przeciwieństwa nad drugim są poważnie zagrożone w nowoczesnej cywilizacji. Tym, czego dotkliwie brakuje dzisiejszemu światu, jest, zdaniem Baumana, właśnie umiar, a znienawidzona przez starożytnego myśliciela hybris (pycha) święci triumfy w płynnej nowoczesności.

Polski filozof symboliczną Heraklitejską rzekę zastępuje - bardziej adekwatną w odniesieniu do realiów obecnego świata - koncepcją płynnego stanu skupienia. Nasilające się od drugiej połowy XX wieku procesy globalizacji dokonywały „coraz szybszego 'skraplania się' struktur i instytucji społecznych"3, czyli zacierania ich granic, zatracania jasno sprecyzowanych funkcji i znaczeń. Owo skraplanie stanowiło główną siłę napędową społeczeństwa: „Płyn’ nie może zachować kształtu i nie wlany do naczynia będzie nieustannie się zmieniać pod wpływem najmniejszych nawet sił. W płynnym stanie skupienia" nie można „powstrzymać ciągłej kapaniny, sączenia się, przemakania" i ostatecznego rozmięknienia ${ }^{4}$.

Tak rozumiana płynność nie jest już wyłącznie Heraklitejską zmiennością jako fundamentalną cechą świata, z poziomu ontologicznego zostaje ona przeniesiona do obszaru życia społecznego, w którym naczelną wartością jest prędkość przemian modernizacyjnych. W efekcie rodzi się pytanie o formy funkcjonowania jednostki (a także społeczeństwa i całej kultury) w warunkach płynnej nowoczesności zarówno w obszarze życia zbiorowego, jak i, co dla nas szczególnie istotne, w sferze codzienności. Socjofilozoficzne rozstrzygnięcia Baumana wyraźnie korespondują z intuicjami i konstatacjami wyrażonymi w formie literackiej przez Wiktora Pielewina w powieści Generation „П” (1999). Diagnoza naukowa spotyka się $\mathrm{z}$ diagnozą artystyczną w pesymistycznym przeświadczeniu o upadku współczesnej kultury jako przestrzeni wartości duchowych, o deficycie tożsamości i nowych zagrożeniach, generujących nieznane wcześniej lęki. Kultura płynnej nowoczesności, zgodnie stwierdzają socjolog i literat, uwzględnia wyłącznie rynkowy mechanizm rentowności,

3 Z. Bauman, Tożsamość. Rozmowy z Benedetto Vecchim, przeł. J. Łaszcz, GWP, Gdańsk 2007, s. 49.

4 Tamże. 
orientuje się jedynie na instrumentalizm i pragmatyzm. To kultura, która mówi językiem zysku i strat, by odwołać się do innego autorytetu, Theodora Adorno ${ }^{5}$. Merkantylizacja codziennego życia „uprawomocnia permanentną modyfikację, zastępowanie i udoskonalanie siebie oraz świata"6. Kryteria, za pomocą których ocenia się wartość ludzkich zachowań, poglądów, postaw, a także wartość idei i zasad, są kryteriami rynku konsumpcyjnego. Przyjemność codziennego konsumowania stała się nadrzędną wartością normatywną społeczeństwa płynnej nowoczesności. „Globalna komodyfikacja, czyli utowarowienie wszelkich możliwych sfer życia" , w tym również doświadczenia potocznego - najpełniej definiuje dzisiejszą kulturę.

W powieści Generation „П” Pielewin dokonuje wiwisekcji jednego z najpotężniejszych i najbardziej skutecznych, jego zdaniem, motorów napędowych gospodarki konsumpcyjnej, jakim jest reklama. Pisarza interesują płynące z tego źródła zagrożenia dla realizującego się w codziennym bycie bezpieczeństwa ontologicznego. Chodzi o jedną z najbardziej fundamentalnych kwestii życia ludzkiego - bezpieczeństwo egzystencjalne rozumiane jako „bezpieczeństwo ontologiczne” odnoszące się do „ufności, z jaką większość istot ludzkich traktuje ciągłość własnej tożsamości oraz stałość otaczającego je środowiska społecznego i materialnego. Przekonanie o wiarygodności osób i rzeczy, tak istotne dla pojęcia zaufania, jest podstawą poczucia ontologicznego bezpieczeństwa"8. Idąc za myślą Anthony'ego Giddensa, Catarina Kinnvall stwierdza, że bezpieczeństwo ontologiczne polega na przekonaniu, iż codzienny, „zwykły bieg rzeczy toczy się po właściwych (i solidnych) torach, oraz że z optymizmem można spoglądać w przyszłość"9.

5 Zob. M. Urbaniak, Gorzki posmak płynnej nowoczesności. Wybrane zagadnienia z filozofii społecznej Zygmunta Baumana, „Kwartalnik Naukowy Uczelni Vistula” 2014, nr 4, s. 9.

6 Tamże, s. 9.

7 Tamże.

8 A. Giddens, Nowoczesność $i$ tożsamość. „Ja” i spoleczeństwo $w$ epoce późnej nowoczesności, przeł. A. Szulżycka, PWN, Warszawa 2001, s. 57. Katarzyna i Andrzej Zybertowiczowie definiują bezpieczeństwo ontologiczne jako „poczucie podmiotu, że zachowuje on pewien obszar sprawstwa odnośnie do biegu zdarzeń, które postrzega jako dla siebie istotne/ważne”. K. i A. Zybertowiczowie, Okietznać zmianę. Bezpieczeństwo ontologiczne, rozwój technologiczny a kryzys Zachodu, „Filo-Sofija” 2017, nr 36, s. 521-538.

9 Z. Danielewicz, Bezpieczeństwo egzystencjalne i specyfika jego wybranych noetycznych zagrożen,, „Studia Koszalińsko-Kołobrzeskie” 2016, nr 23, s. 295. Tutaj konieczne jest uściślenie, że tak rozumiane bezpieczeństwo egzystencjalne 
Niezbywalne dla bezpieczeństwa ontologicznego poczucie trwałości jednostkowej tożsamości nie może być ustanowione w czasach płynnej nowoczesności z racji przesytu rynku oferującego nadmiar dóbr i wartości charakteryzujących osobowość człowieka. Bauman i Pielewin zgodnie przyznają, że definicja jednostki płynnej nowoczesności to definicja współczesnego konsumenta, a hedonistyczna przyjemność ciągłego konsumowania zafiksowała jego rozwój mentalny na poziomie fazy oralnej, co w powieści Generation, $\Pi$ ” zostaje wyrażone przez dyskredytujące epitety:

[...] оранус - примитивный виртуальный организм паразитического типа. [...] Ему недоступно ни абстрактное мышление, ни даже саморефлексия;

У орануса нет ни ушей, ни носа, ни глаз, ни ума. [...] Это бессмысленный полип, лишенный эмоций или намерений, который глотает и выбрасывает пустоту;

иллюзорная структура, у которой нет центра, хотя все предметы и свойства соотносятся через фикцию этого центра, называемую identity [...]. Identity - это фальшивое эго, и этим все сказано ${ }^{10}$.

Problem z samookreśleniem $\mathrm{w}$ dobie płynnej nowoczesności to posiadanie zbyt dużej liczby wyborów w kształtowaniu własnego obrazu, gdy wszystkie wybory wydają się równie atrakcyjne - „rynek konsumenta” oferuje „całą gamę tożsamości [...] nabywca może z rozmysłem kupować symbole takiej tożsamości, do jakiej aspiruje" ${ }^{11}$. Niezliczona rzesza ekspertów dba każdego dnia o dostarczenie gotowego całościowego modelu osobowości pod szyldem znanej marki. Pozwala to konsumentowi usytuować się w ramach konkretnej tożsamości. Bohater Pielewina mówi: „путь к себе’ - это магазин”"2. Finalnie więc podmiotowość zostaje nabyta w krótkim czasie jako gotowy produkt. Niestety, jak słusznie zauważa Bauman, „nigdy nie wiadomo na

nie jest tożsame z wolnością od lęku/niepokoju egzystencjalnego - stałej i w zasadzie nieprzezwyciężalnej przypadłości jednostek, a także społeczeństw. „Nie da się uniknąć ontologii lęku, to znaczy wpisania go w sytuację bycia-wświecie”, rzucenia w chaos świata, skazania na permanentną troskę i niepewność wyborów spośród szeregu przeciwstawnych możliwości. „Nasza ontologiczna kruchość jest funkcją czasowości”, a także poczucia „absurdu”, „bezsensu rzeczywistości, nihilizmu aksjologicznego”. K. Tarnowski, Lęk i nadzieja, „Znak” 2009, nr 653, s. 106-113.

${ }^{10}$ В. Пелевин, Generation „П”, ЭКСМО, Москва 2007, s. 134, 136, 139.

${ }^{11}$ Z. Bauman, T. May, Socjologia, przeł. J. Łoziński, Wydawnictwo Zysk i S-ka, Poznań 2004, s. 129.

${ }^{12}$ В. Пелевин, Generation „П”..., s. 57. 
pewno, czy aktualna” w danym dniu „tożsamość jest najlepsza i dająca największą satysfakcję"13. Skomponowana naprędce sztuczna osobowość jest bytem niezwykle płynnym, rodzajem maski wykreowanej wyłącznie na bieżące potrzeby rynku. Ten zaś skwapliwie dba o poszerzanie oferty nowych, bardziej atrakcyjnych osobowości. Możliwości określenia samego siebie wydają się nieograniczone, albowiem równie nieograniczone są kombinacje reklamowanych przedmiotów. Pielewinowski bohater stwierdza: „Самоидентификация возможна только через составление списка потребляемых продуктов, а трансформация - только через его изменение" 14 . W ten sposób poczucie tożsamości w nowoczesnym świecie zagrożone jest, jak wszystko inne, błyskawiczną przemijalnością. Bardziej problematyczne wydaje się jednak nie to, że „narracja biograficzna jest wciąż na bieżąco weryfikowana”, lecz fakt, że proces ten „rozgrywa się w kontekście wielokrotnego wyboru zapośredniczonego przez systemy abstrakcyjne" ${ }^{15}$, jakim są media. Budowanie tożsamości w akcie refleksyjnej samoobserwacji zastępuje kompulsywna kontrola zmieniających się codziennie medialnych projektów tożsamościowych, co skutkuje ubezwłasnowolnieniem przez reżim abstrakcji. W „myśleniu autobiograficznym” kluczową rolę odgrywa „poczucie spójności historii własnego życia"16. Próba ustanowienia takiej spójności, scalonej, trwałej podmiotowości jednostki zdaje się wysiłkiem skazanym na niepowodzenie. Myślenie o autobiografii jako o czymś wciąż umykającym wywołuje poczucie bezradności i beznadziei:

Aporia pozostaje nierozstrzygnięta - gorączkowo zmieniamy, modernizujemy i ulepszamy siebie oraz swoje otoczenie, dążąc do wyczekiwanego stanu satysfakcji, lecz proces ten z założenia nie może posiadać etapu ostatecznego, gdyż poczucie zadowolenia i zaspokojenia pragnień oznacza społeczną śmierćc ${ }^{17}$.

Rynek konsumencki może sprawnie funkcjonować tylko wtedy, gdy „pragnienia odbiorców są systematycznie podsycane, dlatego też działalność marketingowo-brandingowa stała się współcześnie sztuką generowania nowych potrzeb bez możliwości ich ostatecznego zaspokojenia"18. Doskonale rozumie ten mechanizm główny bohater

${ }^{13}$ Z. Bauman, Tożsamość. Rozmowy..., s. 80.

14 В. Пелевин, Generation „П”..., s. 138.

${ }^{15}$ A. Giddens, Nowoczesność i tożsamość..., s. 8-9.

16 Tamże, s. 100-101.

${ }_{17}$ M. Urbaniak, Gorzki posmak..., s. 15.

${ }_{18}$ Tamże, s. 17. 
Pielewina Tatarski robiący w reklamowym biznesie zawrotną karierę. Rolą stworzonych przez niego klipów reklamowych jest roztaczanie pokus, uwodzenie i podsycanie „ekstazy rosnącego popędu” („восторг в растущем зуде") ${ }^{19}$. Płynna tożsamość nowoczesnej jednostki nie potrafi długoterminowo zachowywać jednakowego, ugruntowanego kształtu. Każdego dnia podlega „obsesyjnemu procesowi nieustannej modernizacji, re-formowania się, permanentnej innowacji” ${ }^{20}$. Stale podsycany głód niezadowolenia zmusza do pozbywania się tego, co nieaktualne, wczoraj nabyta tożsamość (w postaci zakupionego produktu) następnego dnia może okazać się bezużyteczna, nieprzydatna, gdyż nie pasuje do lansowanych aktualnie trendów. Skrzętnie skrywanym sekretem marketingu jest kuszenie konsumentów, tak by pragnienia pozostawały niezaspokojone. W powieściowym świecie Pielewina właściwość tę narrator ujmuje w słowa:

[...] виртуозные мастера жанра, которых он [Tatarski - В.Ż.] видел иногда по телевизору, ухитрялись продавать самое высокое ежедневно, но таким образом, что не было никаких формальных поводов сказать, будто они что-то продали, и на следующий день они могли смело начинать все заНово $^{21}$.

Ten rodzaj cynicznej wirtuozerii Bauman nazywa „ekonomią oszustwa”, które, co znamienne, nie ma charakteru dysfunkcji, lecz jest „gwarancją właściwego działania i jedyną zasadą, która może zapewnić przetrwanie" ${ }^{22}$. Każdego dnia rynek wchłania, przekształca i skazuje na natychmiastowe zapominanie zarówno towary, jak i ich konsumentów. Wspomniany geniusz reklamy Tatarski, który sloganem „Ojczyste dymy słodkie są i miłe” („и дым отечества нам сладок и приятен”)23 reklamującym papierosy „Parłamient”, uchwycił wprawdzie bieżącą chwilę, doznał jednakże przykrego uczucia niepewności na widok spotu innego wirtuoza reklamy, promującego konkurencyjną markę papierosów. Z bólem skonstatował: „Парламент быстро стал самым популярным в Москве сортом сигарет и теперь стоит в два раза дороже. Впоследствии дым отечества

${ }^{19}$ В. Пелевин, Generation „П”..., s. 78. Tłumaczenie za: W. Pielewin, Generation 'P', przeł. E. Rojewska-Olejarczuk, W.A.B., Warszawa 2002, s. 68.

${ }^{20}$ M. Urbaniak, Gorzki posmak..., s. 21.

${ }^{21}$ В. Пелевин, Generation „П”..., s. 34.

${ }^{22}$ Z. Bauman, Ptynne życie, przeł. T. Kunz, Wydawnictwo Literackie, Warszawa 2007, s. 129.

${ }^{23}$ В. Пелевин, Generation „П”..., s. 71. Tłumaczenie za: W. Pielewin, Generation 'P'..., s. 62. 
так и канул в Лету" ${ }^{24}$. Przykrą świadomość nieuniknionej tymczasowości stworzonego produktu wzmaga w bohaterze lęk przed ulotnością własnego istnienia w reklamowej branży. Jest niemal pewne, że ta sama rzeka zapomnienia, która skazała na wieczny niebyt atrakcyjny jeszcze wczoraj i wielce pożądany spot reklamowy, pochłonie lada dzień także jego twórcę. Stąd też Tatarski każdego dnia odczuwa obsesyjny lęk przed niesprostaniem chimerycznym potrzebom rynku. Niechybnie skutkowałoby to nie tylko utratą władzy nad bezwolnymi oranusami, ale czymś znacznie gorszym - zrównaniem z nimi. Obserwuje już taki mechanizm u swych kolegów-copywriterów, ich również spopiela ogień codziennej konsumpcji. Pielewin wprowadził do powieści motyw kartagińskiej kopalni, zwanej też tofetem lub gehenną. Tak w mitologii starożytnej Mezopotamii określano doły, w których palono dzieci składane w ofierze bóstwu Baalowi. Współczesny świat również ma swego Baala - rolę spalarni śmieci pełnią media: „Материальный огонь - это и есть ваш мир. [...] человек в этой жизни присутствует при сжигании мусора своей identity" ${ }^{25}$ - mówi jedna z postaci utworu - tajemnicza zjawa sirruf. Widmo uzmysławia Tatarskiemu, że jego zadaniem jako „kreatora rzeczywistości" jest skłanianie oranusów, by wpatrywali się każdego dnia w płomień konsumpcji: „Огонь, в котором вы сгораете, надо обслуживать. И ты относишься к обслуживающему персоналу”"2. Pozbawiony zdolności do refleksji, a co za tym idzie - wyzuty z podmiotowości konsument, nie zdając sobie z tego sprawy, wiedzie egzystencję śmieciową: „А мусор - это и есть его незнание. Это identity, которой на самом деле нет. [...] Вы все равно не знаете, что с этими жизнями делать. И куда бы вы ни глядели, вы все равно глядите в огонь, в котором сгорает ваша жизнь" ${ }^{27}$. Jednakże w dobie płynnej nowoczesności do tej samej spalarni śmieci trafiają również obsługujący ogień. To jedynie kwestia czasu. Nie ochroni Tatarskiego przed śmietnikiem ani błyskotliwa kariera, ani nawet „boska władza” nabyta podczas rytualnych zaślubin z legendarną boginią Isztar, symbolizującą w powieści „ideę złota”. Boska potęga copywritera jest nie tylko tymczasowa, ale w istocie bardzo złudna, sprowadza się jedynie do „objawiania za pomocą obrazu telewizyjnego”. Źródło rzeczywistej władzy pozostaje poza zasięgiem boskiego Tatarskiego, odpowiedź

${ }^{24}$ В. Пелевин, Generation „П”..., s. 73.

${ }^{25}$ Tamże, s. 191.

${ }^{26}$ Tamże, s. 187.

${ }_{27}$ Tamże, s. 191. 
na nurtujące go pytanie „Kto tym wszystkim rządzi” nigdy nie wybrzmi. W czasach płynnej nowoczesności władza stała się abstrakcyjna i niedefiniowana przez jakiekolwiek instytucje, jak wszystko inne podlega ona nieskończonej cyrkulacji, podmiot i przedmiot władzy wymieniają się pozycjami. Jeśli więc Tatarski jako genialny kreator rzeczywistości jest pozycjonowany $\mathrm{w}$ stosunku do władzy podmiotowo, a odbiorcy jego reklamowych komunikatów - przedmiotowo, to w ostatecznym rezultacie obie strony zostaną uprzedmiotowione, a raczej utowarowione, uznane za bezużyteczne i trafią na społeczny śmietnik. Końcowym produktem konsumpcji stają się wszyscy, każdy zostaje zużyty, skonsumowany. Czasy płynnej nowoczesności znacznie poszerzyły ekstensję pojęcia odpadu, które „denotuje obecnie nie tylko obiekty materialne, także idee, abstrakcje, oraz istoty ludzkie. Jak wszystkie śmieci, ludzi-odpady postrzega się jako bezużytecznych, bezdochodowych" ${ }^{28}$. Każdy może znaleźć się na społecznym wysypisku ludzkich odpadów, niezależnie od posiadanych przywilejów czy dóbr, ponieważ wszyscy postrzegani są poprzez pryzmat konsumpcyjnej rentowności lub jej braku - zgodnie konkludują socjolog i literat. Idea ekonomicznej zbędności oznacza „społeczną bezdomność z towarzyszącą jej utratą poczucia własnej wartości i sensu życia"29.

Życie w epoce płynnej nowoczesności codziennie drastycznie przypomina o powszechnej, błyskawicznej przemijalności wszystkiego bez wyjątku. Nie ma w istocie niczego trwałego, każdy użyteczny i niezbędny dzisiaj przedmiot jutro powędruje na śmietnik. Nic nie jest „absolutnie konieczne, nic nie jest niezastąpione. Żaden krok i żaden wybór nie są ostateczne i nieodwołalne. Nad mieszkańcami świata płynnej nowoczesności unosi się widmo zbędności”" ${ }^{30}$. Tu właśnie tkwią powody codziennej frustracji, wszyscy boją się wykluczenia z luksusu konsumpcji. Permanentne uczucie strachu przed zbędnością zrównuje kreatorów rzeczywistości z oranusami - jedni i drudzy padają ofiarą rynku.

O ile człowiek początku XX wieku był definiowany poprzez Heideggerowską kategorię bycia-ku-śmierci ${ }^{31}$, o tyle kondycję jednostki

${ }^{28}$ Z. Bauman, Życie na przemiat, przeł. T. Kunz, Wydawnictwo Literackie, Kraków 2005, s. 66.

${ }^{29}$ Tamże, s. 26.

${ }^{30}$ M. Urbaniak, Gorzki posmak..., s. 7.

${ }^{31}$ Śmierć jest tu najwyższym i ostatecznym świadectwem bycia. M. Heidegger, Przyczynki do filozofii. Z wydarzania, przeł. B. Baran, J. Mizera, Wydaw. Baran i Suszczyński, Kraków 1996, s. 265. 
epoki płynnej nowoczesności określa nowa kategoria: bycie-ku-wy-

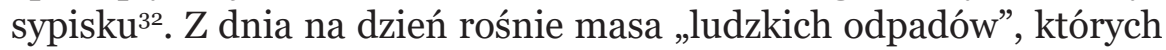
codzienną egzystencję wypełnia jedynie kompulsywne konsumowanie towarów, a jednocześnie - wbrew ich świadomości - bycie konsumowanym przez rynek. Czujność konsumenta skutecznie usypia reklama, obiecując jednocześnie rozwiązanie dysonansu poznawczego. Jeden ze spotów reklamowych Tatarskiego dotyczący biura nieruchomości brzmi: „Дамы и господа! За этими стенами вас никогда не коснется когнитивный диссонанс! Поэтому вам совершенно незачем знать, что это такое"з3. Deklarowana w haśle gwarancja uchronienia konsumenta przed poznawczą i emocjonalną dezorientacją jest ze wszech miar fałszywa. Sugeruje bowiem, że egzystencjalne bezpieczeństwo może być osiągnięte wyłącznie poprzez całkowitą lojalność i ufność wobec reklamy. Tymczasem tylko lojalność w stosunku do samego siebie stwarza realną szansę zbudowania własnego systemu przekonań, niezbędnego dla „ja” prawdziwego. Dla samorealizacji podstawowe punkty odniesienia powinny być ustanawiane „od wewnątrz”, w zależności od tego, jak jednostka „konstruuje i rekonstruuje swoją historię"34. Jeśli punkt odniesienia lokowany jest na zewnątrz $\mathrm{w}$ procesie narzucania jednostce autobiografii, musi ona „podążać po cudzych śladach, które zawsze wiodą donikąd, do ja fałszywego, w najlepszym przypadku do ‘ja' nieokreślonego"35. Mówiąc słowami Pielewina i Baumana - do „ja” śmieciowego. O ile „zaufanie do doświadczeń codzienności jest warunkiem bezpieczeństwa ontologicznego" ${ }^{36}$, to płynna codzienność pozbawia konsumenta tego rodzaju elementarnej ufności. Czy można bowiem ufać dniu wypełnionemu iluzorycznymi treściami? Jak zaufać codzienności będącej doświadczaniem chaosu informacyjnego, zawrotnego przyspieszenia, relatywizmu wartości? Każdy dzień wymusza adaptację do nowych warunków, co skutkuje utratą wiary we własne umiejętności przystosowawcze, ale też w zdolność dekodowania dynamicznie zmieniających się znaczeń i sensów. Nie sposób ustanowić zasad porządkujących rzeczywistość. Ten niezwykły pęd i szum informacyjny skazują na natychmiastowe zapominanie - to, co dziś jest użyteczne, jutro staje się odpadem.

\footnotetext{
${ }^{2}$ Por. M. Urbaniak, Gorzki posmak..., s. 17.

${ }^{33}$ В. Пелевин, Generation „П”..., s. 114.

${ }^{34}$ A. Giddens, Nowoczesność i tożsamość..., s. 111.

35 Tamże.

${ }^{36}$ Tamże, s. 55 .
} 
Istotną rolę w procesie budowania podstawowej ufności odgrywa codzienna organizacja czasu i przestrzeni, między innymi drogą rutynizacji powszechnych czynności, „stabilizowania wzorów”37.

[Rutyna] stabilizuje świat obiektów i ludzi, zaspokaja elementarną ludzka potrzebę sensu i rozumienia codziennie przeżywanej rzeczywistości. Porządek rutyny przyczynia się do powstawania wykształconych struktur istnienia, bo daje poczucie bycia i tworzy zasadniczą dla bezpieczeństwa ontologicznego różnicę w stosunku do „niebycia” ${ }^{8}$.

Tak rozumiana rutynizacja codzienności, zakładająca świadomą troskę o porządek i ład swego świata nie może stać się doświadczeniem konsumenta. Nie rozumie on, że pospolitość i prozaiczność dnia codziennego to w istocie wielka filozofia rzeczy małych, generująca poczucie podstawowej ufności wobec siebie i otaczającego świata. Rutyna dnia konsumenta, sprowadzająca się wyłącznie do bezrefleksyjnego mechanicznego pochłaniania i wydalania skazuje go na ontologiczny niebyt. Narrator Pielewina mówi wprost o niebycie kolektywnym zmanipulowanych przez media telewidzów, impulsywnie i bezwiednie przełączających kolejne kanały telewizyjne:

Возникает виртуальный субъект, который на время телепередачи существует вместо человека, входя в его сознание как рука в резиновую перчатку. [...] Происходящее уместно назвать опытом коллективного небытия, поскольку виртуальный субъект, замещающий собственное сознание зрителя, не существует абсолютно - он всего лишь эффект, возникающий в результате коллективных усилий монтажеров, операторов и режиссера ${ }^{39}$.

Zawrotne tempo i niesłychany dynamizm epoki płynnej nowoczesności powodują specyficzne rozpłynięcie czasu i przestrzeni. Przestrzenne rozeznanie miejsca, w jakim bytuje konsument, nie jest możliwe z racji zatarcia granicy między sferą odczuwaną jako osobista, intymna, pozytywnie zrutynizowana a kreowaną przez wirtuozów reklamy. Kreacja tej przestrzeni nie jest w istocie niczym innym jak tylko stwarzaniem pozorów realności. O jednym z kreatorów Tatarski

${ }^{37}$ K. i A. Zybertowiczowie, Okiełznać zmianę..., s. 529.

${ }^{38}$ A. Giddens, Nowoczesność i tożsamość..., s. 56.

${ }^{39}$ В. Пелевин, Generation „П”..., s. 128. Tego rodzaju stan zbiorowego nieistnienia jest doskonałym narzędziem panowania nad konsumentami - „subtelnym i efemerycznym, bo głęboko zinternalizowanym psychicznie, a przy tym niezwykle skutecznym”. Zob. M. Urbaniak, Gorzki posmak..., s. 21. 
mówi: „[...] больше всего на свете ему нравилось выдавать продукты своего разыгравшегося воображения за хронику реальных событий” 40 . Ucząc się u doświadczonego kolegi kunsztu, sam Tatarski tworzy spot reklamowy trafnie ilustrujący sztukę sprzedawania wymyślonego świata:

Сама по себе стена, на которой нарисована панорама несуществующего мира, не меняется. Но за очень большую сумму можно купить в качестве вида за окном намалеванное солнце, лазурную бухту и тихий вечер. [...] само окно, для которого покупается вид, тоже нарисовано. Тогда, может быть, и стена нарисована? ${ }^{41}$

Powtarzane określenie „namalowany” jednoznacznie semantyzuje obiekt jako sztucznie powołany do życia, wyobrażony, fantazyjny. Stwarzanie dla konsumentów „fałszywej panoramy życia”, zacieranie granicy, która „dla oczywistości świata, a więc dla równowagi ducha powinna być wyraźna i dobrze widoczna"42, skazuje ich na utratę pewności siebie i przykre poczucie zagubienia. Zakłada ponadto infantylizację człowieka. Tatarski cynicznie wystawiał na sprzedaż obrazy odwołujące się do tak typowej dla człowieka tęsknoty za niezrealizowanymi dziecięcymi marzeniami:

[...] это касалось [...] любой картинки из тех, которые волновали когдато в детстве: пальмы, пароход, синее вечернее небо, - надо было быть клиническим идиотом, чтобы сохранить способность проецировать свою тоску по несбыточному на эти стопроцентно торговые штампы ${ }^{43}$.

Paralelnie z zawłaszczaniem i deformowaniem przestrzeni życiowej konsumenta dokonuje się władanie jego czasem. Chodzi o coś znacznie więcej niż dysponowanie godzinami, jakie codziennie poświęca konsument na oglądanie reklamy lub zakup nowego towaru. Pretensje rynku sięgają znacznie dalej - w przestrzeń pozaczasową, w wieczność. Ilustruje to wyraźnie stosowny cytat: реклама „[...] стремится убедить, что потребление рекламируемого продукта

${ }^{40}$ В. Пелевин, Generation „П”..., s. 88.

${ }^{41}$ Tamże. Zdumiewająco Pielewinowski motyw malowania świata koresponduje z tym, co pisze Bauman na temat wizji ustabilizowania „dryfującej tożsamości” epoki ponowoczesnej: „na podobiznach malowanych farbami dzisiejszych doświadczeń świat nie wywiera wrażenia solidności i trwałości”. Z. Bauman, Ponowoczesność jako źródło cierpień, Wydawnictwo Sic!, Warszawa 2000, s. 43.

${ }_{42}$ Tamże, s. 35.

43 В. Пелевин, Generation „П”..., s. 84. 
ведет к высокому и благоприятному перерождению, причем не после смерти, а сразу же после акта потребления"44. Roztaczana przed konsumentem perspektywa nieśmiertelności nie może nie skusić, bazuje bowiem na najsilniejszym bodajże ludzkim lęku przed skończonością jednostkowego bytu. Wbrew pesymistycznym, aczkolwiek uczciwym projektom Heraklita i Haideggera głoszącym codzienne, bezpowrotne przybliżanie się ku nicości, reklama, roszcząc sobie pretensje do władzy boskiej, oferuje projekt pocieszycielski, uwodzicielską perspektywę wiecznej szczęśliwości, pokonania ziemskich ograniczeń, obietnicę ponownych narodzin: codziennie bliżej nie ku śmierci i pustce, przeciwnie - codziennie bliżej ku nowemu życiu ${ }^{45}$. Sam Tatarski z niekłamaną dumą, przepełniony szczęściem oznajmia, że „żadnej śmierci nie ma”. Pycha kreatora rzeczywistości oraz towarzysząca jej postawa braku bojaźni wobec spraw ostatecznych każą zadać pytanie o sens lęku, ale też bezlęku w epoce ponowoczesnej ${ }^{46}$. Jak dowodzą Pielewin i Bauman, współczesny człowiek-konsument niczego nie obawia się bardziej niż niemożności uczestnictwa w grze rynkowej. Codzienność konsumenta przepełnia jeden rodzaj strachu - jak nadążyć za dynamicznie zmieniającymi się trendami, nie okazać się zbędnym ${ }^{47}$ i nie zostać wyrzuconym na margines społeczny. Jest to w rzeczywistości lęk o sprawy nieistotne, tymczasowe, pozbawione wyższych wartości, podczas gdy bezlęk odnosi się do racji wyższych, takich jak sens życia, śmierć. Należy jednak dokonać pewnego rozróżnienia jakościowego: bezlęk konsumenta nie jest tym samym bezlękiem, jaki odczuwa kreator rzeczywistości. Ten pierwszy to słaby, nędzny i pozbawiony mózgu oranus, który zatracił zdolność rozróżniania realiów od miraży. Nie boi się, bo zaufał reklamie. Nie boi się, bo odczuwanie lęku, jak zauważa Søren Kierkegaard, właściwe jest istocie duchowej, a taką oranus nie jest. Zdaniem filozofa „lęk

44 Tamże, s. 201.

${ }^{45}$ Zasadne wydaje się odczytanie koncepcji boskiej władzy copywriterów w kontekście Legendy o Wielkim Inkwizytorze Dostojewskiego. Tatarski niczym Wielki Inkwizytor przychodzi uwolnić człowieka spod ciężaru ziemskiej niedoskonałej egzystencji. W rozmowie z Wielkim Inkwizytorem Chrystus nazywa trzy najważniejsze siły zdolne zjednać sumienia ludzkie dla poczucia szczęścia kosztem wolności: cud, tajemnica, autorytet. Siłę tej trójcy posiada Tatarski.

46 "Świat ponowoczesny przymierza się do ewentualności życia z niepewnością na stałe, do warunków na zawsze już niepewnych, i to taką niepewnością, jakiej zredukować żadną miarą się nie da”. Z. Bauman, Ponowoczesność jako źródło cierpień..., s. 44.

${ }^{47}$ Nie należy mylić tego rodzaju zbędności z typem „człowieka zbędnego” w literaturze rosyjskiej XIX wieku. 
jest szansą na właściwą egzystencję. Tylko lęk może przeprowadzić człowieka przez otwarty na oścież świat i dać mu przeczucie kierunku. Bez lęku ludzkie wędrówki stają się bezsensownym błąkaniem od jednego mirażu do drugiego" ${ }^{48}$, w Pielewinowskim świecie - od jednej reklamy do drugiej. Według duńskiego filozofa brak lęku oznacza brak „poczucia, że coś rzeczywiście się zdobywa, eksploruje, ku czemuś się zdąża"49. Dodajmy - ku czemuś innemu niż tylko zakup kolejnego towaru. Brak lęku wynika z nieprzeciętnej bezduszności - konstatuje Kierkegaard. Jeśli posłużyć się terminologią duńskiego myśliciela, bezduszność zmanipulowanego, zahipnotyzowanego oranusa należałoby określić mianem przeciętnej, natomiast bezduszność kreatora rzeczywistości - wyjątkowo nieprzeciętnej, ponieważ jego bezlęk wynika z pychy, której oranus nie przejawia. Podczas gdy copywriter działa z pełną świadomością, to zahipnotyzowany przez niego oranus nie odczuwa ani lęku, ani pychy. Jeśli lęk pozwala skonfrontować się z rzeczywistością taką, jaka ona jest: chaotyczną, nieprzewidywalną, płynną, to jest sprawą zrozumiałą, dlaczego copywriter tak usilnie zabiega o uwolnienie konsumenta spod Kierkegaardowskiego strachu. „Nie lękaj się” - uspokaja codziennie telewidza spot reklamowy. Smierci nie ma - przekonuje Tatarski z wyżyn swego majestatu. I kiedy boski kreator uwolnił konsumentów od trwogi, zagłuszył ich sumienia. Oni zaś pokłonili się Tatarskiemu-Baalowi. Na tym polega ich błąd. Błąd kreatora jest bardziej doniosły, właściwie należałoby mówić o winie pychy. Pycha zaś zawsze kroczy przed upadkiem. Pragnienie wyzbycia się lęku jest pułapką dla człowieka, Pielewinowską spalarnią, Baumanowskim śmietnikiem. Wszystkie bezlękowe dusze pochłonie rynek, który nie jest bynajmniej mirażem.

Rosyjski pisarz i polski socjolog-filozof zgodnie konstatują, że cywilizacja dostatku dóbr materialnych błędnie jest kojarzona z czasem szczęśliwości. Ich argumentację warto wzmocnić refleksją Marii Szyszkowskiej, promotorki filozofii codzienności. Pisze ona: „Żeby być szczęśliwym, poza innymi warunkami (subiektywnymi i zróżnicowanymi indywidualnie), niezbędny jest kontakt z drugim człowiekiem, a nie z rzeczami” ${ }^{\circ}$. Należy starannie oddzielać szczęście od

${ }^{48}$ S. Kierkegaard, Pojęcie lęku, przeł. A. Djakowska, ALETHEIA, Warszawa 1996, s. 188.

49 Tamże, s. 189.

${ }^{50}$ M. Szyszkowska, Twórcze niepokoje codzienności, Twój Styl, Warszawa 1999, s. 255. Por. także inne prace tej autorki: Zagubieni $w$ codzienności, Twój Styl, Warszawa 2000; Odcienie codzienności, Kresowa Agencja Wydawnicza, Białystok 2009. 
sensu istnienia, gdyż niebezpieczne w skutkach jest odnajdywanie sensu życia w ulotnych chwilach szczęścia. Pielewin i Bauman powiedzieliby - szczęścia płynnego.

Filozofia codzienności postuluje ważkość doświadczenia potocznego, bowiem właśnie w codzienności „dzieją się wszelkie sprawy zasadniczej wagi” ${ }^{11}$. Inny postulat dotyczy wyzwalania się z wadliwej hierarchii wartości. Fakt ludzkiego istnienia filozofia codzienności wskazuje jako dobro najwyższe. Usensownianie istnienia dokonuje się poprzez doświadczenie potoczne, oparte na niezgodzie wobec rezygnacji z własnego ,ja”, niezgodzie na to, by poddawać się rzeczywistości, zamiast ją przetwarzać. W świecie ponowoczesnym troskę o rozwój osobowości pozostawia się fałszywym idolom, takim jak chociażby reklama. Zwycięża postawa przystosowawcza, mimikra przynosząca wymierne korzyści, choć, jak pokazują Pielewin i Bauman, krótkotrwałe i często złudne. Na sposobie myślenia współczesnej jednostki, a więc zarazem i sposobie jej życia, ciążą negatywnie rozmaite uwodzicielskie teorie, których się nie weryfikuje, lecz które się biernie przyswaja. Stan niedostatku prawdy potęguje język, słów często używa się po to, by odwrócić uwagę od niezaprzeczalnych faktów i zafałszować prawdę. Reklamowy biznes jest tutaj wzorcowym przykładem. Rozwiązaniem alternatywnym wobec negatywnego w skutkach przystosowania człowieka do otaczającej go rzeczywistości jest w filozofii codzienności pozytywne nieprzystosowanie: celebrowanie dnia codziennego, indywidualny rozwój, konsekwentne budowanie własnego „ja”, krytyka, odwaga w kształtowaniu poglądu na świat, dążenie do wyższych wartości. Pozytywne nieprzystosowanie ma charakter twórczy, wyraża samodzielność rozwojową:

[...] zadaniem każdego, w jego własnej codziennej skali, jest wyzwalanie się, kształtowanie w sposób obcy konformizmowi i oportunizmowi. [...] Idzie wszak o to, by rzeczywistość przystosować do własnych coraz lepiej uświadamianych potrzeb - nie zaś odwrotnie ${ }^{52}$.

Człowiek końca XX wieku, pisze Szyszkowska - potwierdzając jednocześnie intuicje Pielewina i Baumana - ucieka przed samym sobą. Szuka tego, co przychodzi z zewnątrz. Unika głębszego namysłu nad własnym życiem i stara się upodobnić do tych, którzy go otaczają. Szyszkowska, w ślad za włoskim filozofem Giorgio del Vecchio, przy-

${ }^{51}$ M. Szyszkowska, Twórcze niepokoje codzienności..., s. 9.

${ }^{52}$ Tamże, s. 14. 
pomina, że podstawowym prawem człowieka jest „prawo do samotności” 53 . Będąc sam na sam ze sobą, jednostka ma szansę na refleksję, krytyczny namysł nad sobą i otaczającą rzeczywistością. Nazbyt dobrze prawidłowość tę rozumieją Pielewinowscy kreatorzy rzeczywistości, dlatego pieczołowicie zabiegają o to, by towarzyszyć człowiekowi w jego codzienności poprzez telewizyjny przekaz. Ich filozofia codzienności opiera się na idei przekształcania osoby w konsumenta realizującego cele ustalone nie przez samego siebie, ale narzucone. Pielewinowski bohater konstatuje: „В наше время люди узнают о том, что они думают, по телевизору" ${ }^{54}$. To media definiują jednostkę, mówią, kim jest, czego pragnie i co dla niej najlepsze. Rozsądniej zaś, powiada Bauman, „ogniskować uwagę na tym, co lepsze, niż uganiać się za tym, co ponoć najlepsze. W zaślepieniu stanem doskonałym łatwo przegapić, zlekceważyć lub zaprzepaścić wiele możliwości drobnych, lecz całkiem realnych ulepszeń"55. Ważkość drobnego najłatwiej uchwycić w doświadczeniu potocznym, w codzienności.

\section{REFERENCES}

Bauman, Zygmunt. May, Tim. Socjologia. Przeł. Łoziński, Jerzy. Wydawnictwo Zysk i S-ka: Poznań 2004.

Bauman, Zygmunt. Ptynne życie. Przeł. Kunz, Tomasz. Wydawnictwo Literackie: Warszawa 2007.

Bauman, Zygmunt. Ponowoczesność jako źródło cierpień. Wydawnictwo Sic!: Warszawa 2000.

Bauman, Zygmunt. Tożsamość. Rozmowy z Benedetto Vecchim. Przeł. Łaszcz, Jacek. GWP: Gdańsk 2007, s. 49.

Bauman, Zygmunt. Życie na przemiał. Przel. Kunz, Tomasz. Wydawnictwo Literackie, Kraków 2005.

Danielewicz, Zbigniew. "Bezpieczeństwo egzystencjalne i specyfika jego wybranych noetycznych zagrożeń.” Studia Koszalińsko-Kołobrzeskie 2016, no. 23, 293-304.

Fattal, Michel. "Słowa i czyny u Heraklita." Archiwum Filozofii Historii i Myśli Spotecznej 2013, vol. 58, 11-16.

Giddens, Anthony. Nowoczesność i tożsamość. „Ja” i społeczeństwo w epoce późnej nowoczesności. Przeł. Szulżycka, Alina. PWN: Warszawa 2001.

Heidegger, Martin. Przyczynki do filozofii. Z wydarzania. Przeł. Baran, Bogdan. Mizera, Janusz. Wydaw. Baran i Suszczyński: Kraków 1996.

Kalaga, Wojciech. Mgławice dyskursu. Podmiot, tekst, interpretacja. Universitas: Kraków 2001.

Kierkegaard, Søren. Pojęcie lęku. Przeł. Djakowska, Alina. ALETHEIA: Warszawa 1996.

${ }_{53}$ M. Szyszkowska, Zarys filozofii prawa, Temida2, Białystok 2000, s. 90.

54 В. Пелевин, Generation „П”..., s. 286-287.

55 Z. Bauman, Ponowoczesność jako źródło cierpień..., s. 106. 
Pelevin, Viktor. Generation „P”. EKSMO: Moskva 2007 [Пелевин, Виктор. Generation „П”. ЭКСМО: Москва 2007].

Pielewin, Wiktor. Generation 'P'. Przeł. Rojewska-Olejarczuk, Ewa. W.A.B.: Warszawa 2002.

Szyszkowska, Maria. Odcienie codzienności. Kresowa Agencja Wydawnicza: Białystok 2009.

Szyszkowska, Maria. Twórcze niepokoje codzienności. Twój Styl: Warszawa 1999.

Szyszkowska, Maria. Zagubieni w codzienności. Twój Styl: Warszawa 2000.

Szyszkowska, Maria. Zarys filozofii prawa. Temida2: Białystok 2000.

Tarnowski, Karol. "Lęk i nadzieja." Znak 2009, no. 653, 106-113.

Urbaniak, Marcin. "Gorzki posmak płynnej nowoczesności. Wybrane zagadnienia z filozofii społecznej Zygmunta Baumana.” Kwartalnik Naukowy Uczelni Vistula 2014, no. 4, 5-27.

Zybertowiczowie, Katarzyna \& Andrzej. "Okiełznać zmianę. Bezpieczeństwo ontologiczne, rozwój technologiczny a kryzys Zachodu.” Filo-Sofija 2017, no. 36, 521-538.

Божена Жеймо

МУСОРНЫЕ БУДНИ КОНСУМЕНТА. РОМАН ВИКТОРА ПЕЛЕВИНА GENERATION „П” В ЗЕРКАЛЕ ТЕОРИИ ТЕКУЧЕЙ СОВРЕМЕННОСТИ ЗИГМУНТА БАУМАНА

Резюме

Целью статьи является анализ романа Виктора Пелевина Generation „П” в контексте теории «текучей современности» польского философа и социолога Зигмунта Баумана. Как российский писатель, так и польский ученый указывают на отрицательные результаты влияния современной - необыкновенно гибкой, текучей, свободной от границ и условий - коммерческой цивилизации на повседневную жизнь человека, его менталитет, систему ценностей, самоидентификацию и чувство собственного достоинства. Философии повседневности, основанной на апофеозе «маленькихдействий» изаботеоличных идеалах, угрожает философия «текучей современности», провозглашающая подражание таким идолам, как реклама и массмедия. 
ŚMIECIOWA CODZIENNOŚĆ KONSUMENTA...

Bożena Żejmo

THE WASTE DAILY LIFE OF CONSOMER. VIKTOR PELEVIN'S

NOVEL GENERATION "P” IN THE LIGHT

OF ZYGMUNT BAUMAN'S THEORY OF LIQUID MODERNITY

Summary

The purpose of the article is to analyze the novel by Victor Pelevin Generation " $P$ " in the context of the theory of "fluid modernity" of the Polish philosopher and sociologist Zygmunt Bauman. Both the Russian writer and the Polish scholar point out the negative effects of the modern - unusually flexible, fluid, free from borders and conditions - commercial civilization on a person's daily life, his mentality, value system, self-identification and selfesteem. 